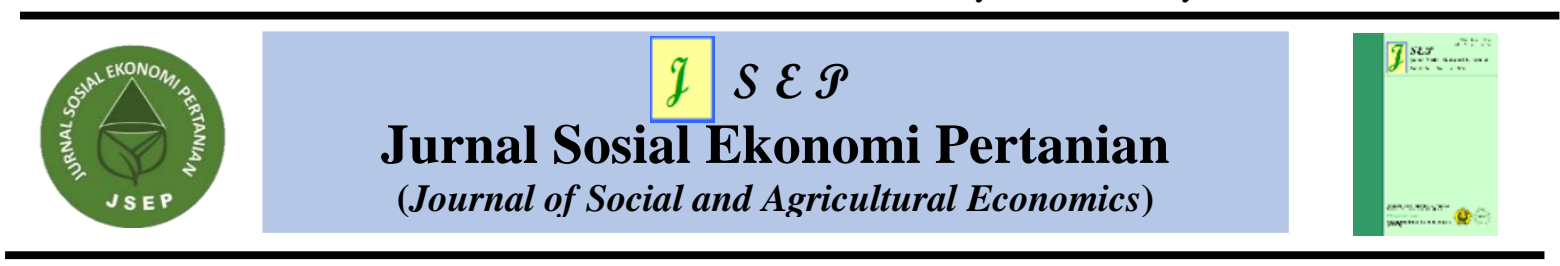

\title{
ANALISIS KELAYAKAN BISNIS PENAMBAHAN INDUK IKAN NILA NIRWANA PADA POKDAKAN MINA NILA SARI PURWAKARTA
}

\section{BUSINESS FEASIBILITY ANALYSIS OF ADDITION OF BROODFISH NIRWANA TILAPIA IN MINA NILA SARI AQUACULTURE GROUP}

\author{
Muhammad Ridho Muhaimin ${ }^{1 *}$, Andan Hamdani ${ }^{1}$ \\ ${ }^{1}$ Program Studi Manajemen Agribisnis, Sekolah Vokasi, Institut Pertanian Bogor \\ J1. Kumbang No. 14 Babakan, Kecamatan Bogor Tengah, Kota Bogor, Indonesia \\ e-mail: ${ }^{1)}$ rmuhaimin04@gmail.com
}

Submitted: 07/05/2021 Revised: 26/07/2021 Accepted: 31/07/2021

\begin{abstract}
Mina Nila Sari Aquaculture Group is an aquaculture group at Legoksari Village, Purwakarta District. Pokdakan Mina Nila Sari have 30 members. Hatchery unit conditions with 43 broodfish packages can not fulfill the larvae demand yet. The purpose of this study was to formulate business development idea addition of broodfish Nirwana tilapia for larvae fulfillment at Mina Nila Sari Purwakarta Aquaculture Group and to analyze the feasibility of this business development study on marketing aspects, production aspects, organization and management aspects, collaboration aspects as non-financial sub aspect and to analysis financial aspect by using Incremental Net Benefit to determine incremental benefit on development business. In terms of analyzing the financial aspect will be using investment criteria namely Net Present Value, Internal Rate of Return, Net Benefit-Cost Ratio, and Payback Period. The result of this study shows business development study addition of broodfish Nirwana tilapia for larvae fulfillment at Mina Nila Sari Purwakarta Aquaculture Group is feasible to "Go”. Calculation of Incremental Net Benefit shows this development business is profitable.
\end{abstract}

Keywords: aquaculture group, broodfish, hatchery, nirwana tilapia

\begin{abstract}
ABSTRAK
Pokdakan Mina Nila Sari merupakan kelompok pembudidaya ikan yang berlokasi di Desa Legoksari Kabupaten Purwakarta. Pokdakan Mina Nila Sari memiliki anggota sebanyak 30 orang. Kondisi unit pembenihan dengan induk sebanyak 43 paket belum cukup untuk memenuhi kebutuhan permintaan larva pokdakan.Tujuan dari penulisan kajian pengembangan bisnis ini yaitu merumuskan ide pengembangan bisnis penambahan induk ikan nila Nirwana untuk pemenuhan kebutuhan larva Pokdakan Mina Nila Sari Purwakarta dan menganalisis kelayakan usaha pengembangan bisnis yang berkaitan dengan aspek pemasaran, aspek produksi, aspek organisasi dan manajemen, aspek kolaborasi sebagai aspek non finansial dan menganalisis aspek finansial dengan melihat perhitungan Incremental Net Benefit untuk mengetahui manfaat tambahan yang diperoleh dalam pengembangan bisnis. Dalam menganalisis aspek finansial digunakan kriteria investasi yaitu Net Present Value, Internal Rate of Return, Net Benefit Cost Ratio dan Payback Period. Hasil dari kajian ini menunjukkan pengembangan bisnis penambahan induk ikan nila Nirwana secara finansial dan non finansial dinyatakan layak dilaksanakan. Perhitungan Incremental net benefit menunjukkan pengembangan bisnis ini menguntungkan untuk dilaksanakan.
\end{abstract}

Kata kunci: Induk, Nila Nirwana, Pembenihan, Pokdakan

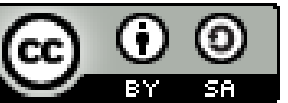

Copyright $\odot 2021$ by Author(s)

This work is licensed under a Creative Commons Attribution-ShareAlike 4.0 International

License. All writings published in this journal are personal views of the authors and do not represent the views of this journal and the author's affiliated institutions.

How to Cite: Muhaimin, M.R., Hamdani, A. (2021). Analisis Kelayakan Bisnis Penambahan Induk Ikan Nila Nirwana Pada Pokdakan Mina Nila Sari Purwakarta. JSEP: Jurnal Sosial Ekonomi Pertanian, 14(2): 201-221. 


\section{PENDAHULUAN}

Budi daya ikan nila Nirwana memiliki beberapa tahapan yaitu pembenihan, pendederan, dan pembesaran. Pembenihan ikan nila Nirwana merupakan tahapan penting karena pada tahapan ini seorang pembudidaya berusaha untuk menghasilkan keturunan-keturunan unggul yang akan berpengaruh kuat kepada tahapan-tahapan selanjutnya. Usaha pembenihan telah banyak dilakukan oleh Unit Pembenihan Rakyat (UPR) yang berbentuk kelompok pembudidaya ikan. Kelompok pembudidaya ikan (Pokdakan) Mina Nila Sari Purwakarta menjadi salah satu unit pembenihan rakyat. Pokdakan Mina Nila Sari merupakan pokdakan yang berlokasi di Desa Legoksari Kabupaten Purwakarta. Pokdakan Mina Nila Sari memiliki anggota sebanyak 30 orang. Sepuluh orang anggota menjalankan unit bisnis pembenihan. Mayoritas anggota menjalankan unit bisnis pendederan.

Pokdakan Mina Nila Sari dalam unit pembenihan saat ini hanya memiliki 43 ekor induk ikan nila Nirwana yang berisi 400 ekor dengan sex ratio antara jantan dan betina adalah 1:3. Total induk yang dimiliki sebanyak 17200 ekor. Induk yang dimiliki bergantung pada program Bantuan Peminjaman Induk (Bapinduk) Ikan Nila Nirwana yang dikelola oleh Balai Pengembangan dan Pemacuan Stok Ikan Nila dan Mas (BPPSINM). Program Bantuan Peminjaman Induk (Bapinduk) Ikan Nila Nirwana ini meminjamkan induk ikan nila Nirwana selama dua tahun. Induk program bapinduk wajib dikembalikan ke Balai Pengembangan dan Pemacuan Stok Ikan Nila dan Mas (BPPSINM). Kondisi unit pembenihan dengan induk sebanyak 43 paket belum cukup untuk memenuhi kebutuhan permintaan larva pokdakan. Strategi pokdakan saat ini untuk menutupi kekurangan larva adalah membeli larva dari pembenih yang bukan anggota pokdakan. Larva yang dibeli dari pembenih tidak dapat dijamin kualitasnya. Larva yang dibeli memiliki kualitas yang tidak baik karena tidak berasal dari induk ikan nila Nirwana dan sudah tercampur dari beberapa varietas. Kualitas larva ini akan merusak citra perusahaan sebagai pembudidaya ikan nila Nirwana.

Pokdakan Mina Nila Sari telah berdiri selama dua tahun. Selama dua tahun pokdakan menjalankan usaha pendederan ikan nila Nirwana dengan output benih ukuran 1-3 cm, $3-5 \mathrm{~cm}$ (barus), dan $5-8 \mathrm{~cm}$ (belo). Bahan baku utama pada produksi unit pendederan adalah larva ikan nila Nirwana. Larva ikan nila Nirwana untuk unit pendederan dipasok oleh unit pembenihan pada pokdakan. Induk yang dimiliki pokdakan hanya dapat memenuhi permintaan sebesar 117,517 juta ekor larva per tahun. Kebutuhan larva Pokdakan Mina Nila Sari sebanyak 248 juta ekor per tahun. Permintaan dan penawaran larva ikan nila Nirwana dapat dilihat pada Tabel 1.

Tabel 1. Penawaran dan Permintaan Larva Pokdakan Mina Nila Sari

\begin{tabular}{cccccr}
\hline $\begin{array}{c}\text { Tahun } \\
\text { Ke- }\end{array}$ & $\begin{array}{c}\text { Permintaan Larva } \\
\text { (000 Ekor) }\end{array}$ & $\begin{array}{c}\text { Penawaran Larva } \\
\text { (000 Ekor) }\end{array}$ & $\begin{array}{c}\text { Selisih } \\
\text { (000 Ekor } \\
\text { Larva) }\end{array}$ & $\begin{array}{c}\text { Pemenuhan } \\
\text { Selisih } \\
(000 \text { Ekor } \\
\text { Larva })\end{array}$ & $\begin{array}{c}\text { Persentase } \\
\text { Pemenuhan Selisih } \\
(\%)\end{array}$ \\
\hline 1 & 248.000 & 117.517 & 130.483 & 100.733 & 77 \\
$2-5$ & 248.000 & 117.517 & 130.483 & 130.483 & 100 \\
\hline
\end{tabular}

Sumber: Pokdakan Mina Nila Sari (2018)

Berdasarkan Tabel 1, selisih antara permintaan dan penawaran adalah 130,483 juta ekor larva per tahun. Kondisi pokdakan saat ini memerlukan sebuah kajian kelayakan untuk mengembangkan bisnisnya agar Pokdakan Mina Nila Sari dapat memenuhi kebutuhan larva secara mandiri dan status kepemilikan induk ikan pokdakan 
menjadi induk milik sendiri. Pengembangan yang akan dilakukan adalah penambahan induk ikan nila nirawana dengan melakukan pembelian induk kepada Balai Pengembangan dan Pemacuan Stok Ikan Nila dan Mas (BPPSINM). Pengembangan usaha ini dilakukan karena kepemilikan induk pokdakan selama ini dengan status pinjam dari Bapinduk. Program Bapinduk tidak memiliki kepastian keberlanjutan yang dapat mengancam bisnis pembenihan dan pendederan ikan nila Nirwana di Pokdakan Mina Nila Sari. Diatin dkk. (2007) telah melakukan kajian kelayakan finansial budidaya ikan nila ras Wanayasa (Nirwana) yang dilakukan oleh Pokdakan Mekarsari. Kelayakan finansial dihitung menggunakan analisis finansial yang terdiri dari pendapatan usaha, $\mathrm{R} / \mathrm{C}$ rasio, payback period, Net Present Value, Net B/C rasio,Internal Rate of Return, dan analisis sensitivitas. Hasil dari analisis kelayakan finansial ikan nila Wanayasa bahwa usaha pembenihan dan pendederan layak untuk dijalankan dan dikembangkan dengan nilai $\mathrm{R} / \mathrm{C}$ rasio sebesar 3,21 dan Net $\mathrm{B} / \mathrm{C}$ rasio sebesar 19,38. Usaha pembenihan dan pendederan tidak sensitif dengan kenaikan harga pakan.

Usaha budidaya ikan Rekan Beumaju di Kabupaten Nagan Raya dinyatakan layak. Ikan yang dibudidayakan merupakan Nila GIFT (Genetic Improvement of Farmer Tilapia). Usaha budidaya dinilai menggunakan parameter kelayakan usaha R/C rasio, payback period, Break Even Point (BEP) dan pemasaran (Amarullah dkk., 2020) Pembenihan yang dilakukan Unit Pembenihan Rakyat (UPR) Syariah Mandiri juga memiliki hasil penilaian layak dan menguntungkan. Keuntungan bersih yang diterima oleh UPR Syariah Mandiri mencapai Rp 1.411.726.300 dengan nilai B/C rasio yang dimiliki sebesar 12,36. Pengembalian investasi yang dinilai dengan payback period sangat cepat yaitu 2 bulan 7 hari. UPR Syariah Mandiri menjalankan usaha pembenihan ikan Mas di Provinsi Sulawesi Utara (Pomuri dkk., 2020).

Penelitian sebelumnya telah memberikan gambaran bahwa usaha budidaya pembenihan ikan sangat menguntungkan dengan perolehan nilai $\mathrm{B} / \mathrm{C}$ rasio mulai dari 12,36 hingga 19,38. Penelitian sebelumnya belum memasukkan aspek non-finansial yang juga sangat berpengaruh terhadap usaha. Penelitian kelayakan usaha ini akan menilai aspek finansial dan aspek non finansial. Aspek finansial dengan menggunakan beberapa kriteria investasi dan menghitung tambahan manfaat yang diterima dari pengembangan bisnis. Aspek non finansial akan dijelaskan secara deskriptif meliputi produk, pemasaran, produksi, sumberdaya manusia, dan kolaborasi.

\section{METODE PENELITIAN}

Penelitian ini dilaksanakan pada Pokdakan Mina Nila Sari yang berlokasi di Kampung Legokwaru, Desa Legoksari, Kecamatan Darangdan, Kabupaten Purwakarta. Lokasi penelitian dipilih dengan menimbang bahwa Pokdakan Mina Nila Sari merupakan Pokdakan dengan kelas Pemula. Pokdakan baru berjalan 2,5 tahun sehingga masih membutuhkan pengembangan usaha untuk naik ke kelas Madya. Waktu pelaksanaan penelitian dimulai dari tanggal 5 Februari 2018 sampai dengan tanggal 28 April 2018. Data dan sumber data yang digunakan dalam penelitian ini menggunakan data primer dan data sekunder. Data primer merupakan data yang diperoleh langsung melalui pengamatan dan dengan mengikuti kegiatan yang dilakukan kelompok serta wawancara dengan anggota kelompok, pelanggan, pemasok, dan pihak - pihak terkait. Data sekunder merupakan data yang diperoleh secara tidak langsung melalui berbagai media. Data sekunder dapat diperoleh melalui berbagai sumber seperti Dinas Peternakan dan Perikanan Kabupaten Purwakarta, dan dokumen - dokumen yang 
dimiliki kelompok. Sumber data penunjang lainnya diperoleh dari media elektronik yang berhubungan dengan topik yang dibahas.

Metode analisis yang digunakan dalam penulisan kajian pengembangan bisnis ini adalah metode kualitatif dan metode kuantitatif. Metode kualitatif merupakan penelitian yang menekankan pada pemahaman mengenai masalah-masalah dan akan dideskripsikan dari data yang telah diperoleh. Metode kualitatif dalam analisis ini digunakan untuk menilai dari sisi aspek non-finansial seperti aspek produksi, aspek pemasaran, aspek organisasi dan manajemen, aspek sumberdaya manusia, dan aspek kolaborasi. Metode kuantitatif dalam kajian pengembangan bisnis ini digunakan untuk menilai dari sisi aspek finansial seperti perencanaan penerimaan, biaya investasi, biaya operasional. Penilaian terhadap aspek finansial yaitu dengan menilai beberapa kriteria investasi seperti penilaian terhadap Net Present Value (NPV), Net Benefit Cost Ratio (Net B/C), Internal Rate of Return (IRR), Payback Period (PP) dan Incremental Net Benefit untuk menghitung tambahan manfaat yang diterima dari pengembangan bisnis. Penilaian terhadap aspek-aspek dilakukan untuk menilai pengembangan bisnis layak atau tidak layak dan menguntungkan atau tidak menguntungkan untuk dijalankan.

\section{Aspek Pemasaran}

Pelaku pemasaran harus memahami secara dekat pasar yang akan menjadi lokasi pemasaran dan harus mengetahui apa yang diinginkan konsumen. Analisis pasar merupakan hal utama dalam sebuah bisnis untuk menciptakan nilai dan hubungan yang menguntungkan dengan pelanggan. Analisis aspek pemasaran akan membahas strategi pemasaran yang bertujuan untuk mengenali kesulurahan pasar meliputi Segmentation, Targetting, dan Positioning (STP). Strategi pemasaran akan membantu perusahaan untuk menciptakan bauran pemasaran yang terdiri dari beberapa faktor yaitu produk (product), harga (price), tempat (place), promosi (promotion) (Kotler \& Amstrong, 2017).

\section{Aspek Produksi}

Aspek produksi merupakan aspek yang mencakup penentuan lokasi, luas produksi tata letak, peralatan produk, proses produksi serta pemilihan teknologi (Kasmir \& Jakfar, 2003). Aspek produksi perlu diperhatikan karena berkaitan dengan produk yang akan dipasarkan kepada konsumen dan tenaga kerja sehingga pada aspek ini harus diperhitungkan secara tepat untuk meminimalisir kesalahan yang akan terjadi. Kesalahan dalam aspek ini mengakibatkan kegagalan bagi perusahaan dalam hal efisiensi, keselamatan kerja, dan kepercayaan konsumen yang akan berdampak pada laba yang dihasilkan perusahaan.

\section{Aspek Organisasi dan Manajemen}

Aspek organisasi dan manajemen dilakukan perusahaan untuk mengadakan perubahan yang positif bagi perkembangan organisasi. Terdapat beberapa variabel yang sangat penting pada aspek organisasi dan manajemen seperti perancangan dan perubahan struktur organisasi, budaya kerja. Tujuan perusahaan dapat tercapai apabila memenuhi tahapan-tahapan dalam proses manajemen. Masing - masing fungsi manajemen tidak dapat berjalan sendiri-sendiri dan harus berjalan secara berkesinambungan karena hubungan antar fungsi sangat erat (Kasmir \& Jakfar, 2003). 


\section{Aspek Sumber Daya Manusia}

Aspek sumberdaya manusia merupakan suatu kegiatan yang dilakukan secara sistematis untuk meramalkan atau memperkirakan kebutuhan sumber daya manusia dalam suatu bisnis atau perusahaan (Kasmir \& Jakfar, 2003). Hal yang perlu dianalisis terkait sumberdaya manusia meliputi perencanaan sumberdaya manusia, rekrutmen, dan pemutusan hubungan kerja. Aspek ini sangat diperlukan sebuah perusahaan karena perusahaan akan dapat menjamin ketersediaan tenaga kerja masa kini maupun masa yang akan datang.

\section{Aspek Kolaborasi}

Analisis aspek kolaborasi adalah menganalisis tentang hubungan bisnis dengan rekan bisnis atau mitranya. Kolaborasi terhadap mitra harus diperkuat sehingga timbul kepercayaan dan sikap saling mendorong dalam meningkatkan profit. Kolaborasi memiliki beberapa konsep yaitu kooperasi dan koopetisi. Kooperasi lebih cenderung ke dalam hubungan yang subsitusi. Hubungan koopetisi merupakan hubungan yang komplementari atau saling melengkapi. Bisnis yang bergerak dalam pasar yang sama diharapkan saling melengkapi untuk bersama-sama meluaskan pangsa pasar (Raharja, 2009). Hubungan kemitraan dapat berupa kolaborasi pemanfaatan sumberdaya, kolaborasi permodalan, kolaborasi penjualan dan pemasaran. Kolaborasi pemanfaatan sumberdaya merupakan kerjasama antar dua atau lebih perusahaan dalam menggunakan sumberdaya salah satu contonya adalah pemanfaatan bangunan. Kolaborasi permodalan adalah hubungan kerjasama dengan perusahaan permodalan atau perorangan untuk mencari tambahan modal yang diperlukan contohnya hubungan kerjasama dengan perusahaan financial technology. Kolaborasi penjualan dan pemasaran adalah kerjasama dengan perusahaan lain untuk menjual produk dengan mekanisme tertentu.

\section{Aspek Finansial}

\section{a. Biaya investasi}

Bisnis yang akan dimulai memerlukan sumber daya yang akan digunakan dalam menjalankan proses produksi. Sumber daya yang diperlukan salah satunya adalah aset. Aset yang dimiliki akan digunakan mulai dari pendirian bisnis sampai bisnis dapat dioperasikan. Pembelian aset mengeluarkan biaya yang disebut sebagai biaya investasi (Kasmir \& Jakfar, 2003). Aset yang digunakan akan selalu dihitung nilai penyusutannya. Perhitungan nilai penyusutan dihitung dengan metode garis lurus. Perhitungan metode garis lurus dengan cara membagi nilai ekonomis aset dengan umur bisnis aset.

b. Biaya operasional

Biaya operasional merupakan biaya yang terdiri dari dua komponen yaitu biaya tetap dan biaya variabel. Biaya operasional didapat dari hasil menjumlahkan total biaya tetap dan biaya variabel sehingga biaya operasional dapat disebut sebagai keseluruhan biaya dalam proses produksi. Jumlah biaya operasional dapat menilai proses produksi pada perusahaan tergolong efisien atau tidak.

c. Proyeksi penerimaan

Penerimaan merupakan uang yang diterima dari hasil penjualan produk perusahaan, Penerimaan akan berbanding lurus dengan jumlah produk yang dihasilkan. Penerimaan dapat dihitung dengan mengalikan jumlah produksi dengan harga jual yang telah ditetapkan. 


\section{d. Laporan laba rugi}

Elemen - elemen yang terdapat dalam laporan laba rugi yaitu penghasilan, harga pokok penjualan, pajak, bunga, dan laba bersih. Format penulisan laporan laba rugi dapat dilihat pada Tabel 2.

Tabel 2 Format laporan laba rugi

\begin{tabular}{|c|c|}
\hline Komponen & Nilai (Rp) \\
\hline Penjualan & $\mathrm{Xxx}$ \\
\hline Biaya variabel & $\mathrm{Xxx}$ \\
\hline Marjin kotor & $\mathrm{Xxx}$ \\
\hline Biaya tetap & $\mathrm{Xxx}$ \\
\hline Laba kotor (EBIT) & $\mathrm{Xxx}$ \\
\hline Bunga & $\mathrm{Xxx}$ \\
\hline Laba sebelum Pajak (EBT) & $\mathrm{Xxx}$ \\
\hline Pajak & $\mathrm{Xxx}$ \\
\hline Laba bersih (EAT) & $\mathrm{Xxx}$ \\
\hline
\end{tabular}

Sumber : Nurmalina et al. (2014)

\section{Arus kas (Cashflow)}

Arus kas adalah model pencatatan uang kas yang masuk dan keluar sebagai dari aktivitas perusahaan. Arus kas merupakan catatan atas arus kas masuk (Inflow) yang berisi atas pendapatan produksi, pinjaman, nilai sewa, hibah, dan nilai sisa. Arus kas juga merupakan catatan atas arus kas keluar (Outflow) yang berisi atas pengeluaran biaya investasi, biaya operasional, pembayaran bunga pinjaman, pajak penghasilan, dan biaya lainnya (Nurmalina et al., 2014). Format penulisan arus kas dapat dilihat pada Tabel 3.

Tabel 3. Format penulisan arus kas

\begin{tabular}{|c|c|c|c|c|c|c|}
\hline \multirow[t]{2}{*}{ No } & \multirow{2}{*}{ Uraian komponen } & \multirow{2}{*}{$\begin{array}{l}\text { Tanpa } \\
\text { bisnis }\end{array}$} & \multicolumn{4}{|c|}{ Dengan bisnis (tahun) } \\
\hline & & & 1 & 2 & $\ldots$ & $\mathrm{n}$ \\
\hline \multirow[t]{7}{*}{$\mathrm{I}$} & Inflow & & & & & \\
\hline & Pendapatan produksi & & $\mathrm{Xxx}$ & $\mathrm{Xxx}$ & $\mathrm{Xxx}$ & $\mathrm{Xxx}$ \\
\hline & Pinjaman & & $\mathrm{Xxx}$ & $\mathrm{Xxx}$ & $\mathrm{Xxx}$ & $\mathrm{Xxx}$ \\
\hline & Nilai sewa & & $\mathrm{Xxx}$ & $\mathrm{Xxx}$ & $\mathrm{Xxx}$ & $\mathrm{Xxx}$ \\
\hline & Hibah & & $\mathrm{Xxx}$ & $\mathrm{Xxx}$ & $\mathrm{Xxx}$ & $\mathrm{Xxx}$ \\
\hline & Nilai Sisa & & $\mathrm{Xxx}$ & $\mathrm{Xxx}$ & $\mathrm{Xxx}$ & $\mathrm{Xxx}$ \\
\hline & Total inflow & & $\mathrm{Xxx}$ & $\mathrm{Xxx}$ & $\mathrm{Xxx}$ & $\mathrm{Xxx}$ \\
\hline \multirow[t]{7}{*}{ II } & Outflow & & & & & \\
\hline & Biaya investasi & & $\mathrm{Xxx}$ & $\mathrm{Xxx}$ & $\mathrm{Xxx}$ & $\mathrm{Xxx}$ \\
\hline & Biaya operasional & & $\mathrm{Xxx}$ & $\mathrm{Xxx}$ & $\mathrm{Xxx}$ & $\mathrm{Xxx}$ \\
\hline & Pembayaran bunga pinjaman & & $\mathrm{Xxx}$ & $\mathrm{Xxx}$ & $\mathrm{Xxx}$ & $\mathrm{Xxx}$ \\
\hline & Pajak penghasilan & & $\mathrm{Xxx}$ & $\mathrm{Xxx}$ & $\mathrm{Xxx}$ & $\mathrm{Xxx}$ \\
\hline & Biaya lainnya & & $\mathrm{Xxx}$ & $\mathrm{Xxx}$ & $\mathrm{Xxx}$ & $\mathrm{Xxx}$ \\
\hline & Total outflow & & $\mathrm{Xxx}$ & $\mathrm{Xxx}$ & $\mathrm{Xxx}$ & $\mathrm{Xxx}$ \\
\hline III & Net benefit dengan bisnis $=(\mathrm{I}-\mathrm{II})$ & & & & & \\
\hline IV & Net benefit tanpa bisnis $=($ I-II $)$ & & & & & \\
\hline V & Incremental net benefit $=($ III-IV $)$ & & & & & \\
\hline VI & $\begin{array}{l}\text { Discount factor } \\
\text { PV net benefit }(\mathrm{NPV})=(\mathrm{V}) *(\mathrm{VI})\end{array}$ & & & & & \\
\hline
\end{tabular}

Sumber : Nurmalina et al. (2014) 


\section{Kriteria Investasi}

a. $\quad$ Net Present Value (NPV)

Net Present Value adalah nilai saat ini dari keuntungan bersih (manfaat bersih) yang akan diperoleh pada masa depan. Nilai yang dihasilkan dari perhitungan NPV adalah sebegai berikut:

Keterangan:

$$
\mathrm{NPV}=\sum_{\mathrm{t}=1}^{\mathrm{n}} \frac{\mathrm{Bt}}{(1+\mathrm{t})^{\mathrm{t}}}-\sum_{\mathrm{t}=1}^{\mathrm{n}} \frac{\mathrm{Ct}}{(1+1)^{\mathrm{t}}}=\sum_{\mathrm{t}=1}^{\mathrm{n}} \frac{\mathrm{Bt}-\mathrm{Ct}}{(1+1)^{\mathrm{t}}}
$$

$\mathrm{Bt}=$ Manfaat pada tahun $\mathrm{t}(\mathrm{Rp})$

$\mathrm{Ct} \quad=$ Biaya pada tahun $\mathrm{t}(\mathrm{Rp})$

$\mathrm{t} \quad=$ Tahun kegiatan bisnis

$\mathrm{i} \quad=$ Tingkat DR $(\%)$

$\mathrm{n} \quad=$ Umur ekonomis proyek (tahun)

Kriteria penilaian untuk Net Present Value (NPV) sebuah bisnis dikatakan layak jika nilai NPV >0. Tidak layak jika nilai NPV $<0$. Bisnis masih dapat dijalankan walaupun tidak menghasilkan keuntungan ketika nilai NPV $=0$.

\section{b. $\quad$ Net Benefit Cost Ratio ( Net B/C)}

Net $\mathrm{B} / \mathrm{C}$ yaitu rasio antara manfaat bersih positif dengan manfaat bersih negatif (Nurmalina et al., 2014). Kriteria dari Net B/C dikatakan layak jika Net B/C > 1. Usaha akan dikatakan tidak layak jika nilai Net $\mathrm{B} / \mathrm{C}<1$.

\section{Keterangan:}

$$
\operatorname{Net} \frac{B}{C}=\frac{\sum_{t=1}^{n} \frac{B_{t}-C_{t}}{(1+i)^{t}}}{\sum_{t=1}^{n} \frac{B_{t}-C_{t}}{(1+i)^{t}}}=\text { Syarat } \quad \begin{aligned}
& \left(B_{t}-C_{t}\right)>0 \\
& ------ \\
& \left(B_{t}-C_{t}\right)<0
\end{aligned}
$$

$\mathrm{Bt}=$ Manfaat pada tahun $\mathrm{t}$

$\mathrm{Ct} \quad=$ Biaya pada tahun $\mathrm{t}$

$\mathrm{t}=$ Tahun kegiatan bisnis

$\mathrm{i} \quad=$ Tingkat DR $(\%)$

\section{c. Internal Rate of Return (IRR)}

Internal rate of return (IRR) adalah tingkat suku bunga maksimum yang dapat dibayar oleh bisnis untuk sumberdaya yang digunakan karena bisnis kembali membutuhkan dana untuk pembiayaan operasi dan investasi, serta bisnis baru hingga pada tingkat pulang modal. Suatu bisnis dapat dikatakan layak apabila memiliki nilai IRR lebih besar dari nilai bunga pembanding (kredit atau deposito) (Nurmalina et al., 2014). IRR dapat dirumuskan sebagai berikut:

Keterangan:

$$
\mathrm{IRR}=\mathrm{i}_{1}+\frac{\mathrm{NPV}_{1}}{\mathrm{NPV}_{1}+\mathrm{NPV}_{2}} \times\left(\mathrm{i}_{2}-\mathrm{i}_{1}\right)(3)
$$

$\mathrm{i}_{1} \quad=$ Discount rate yang menghasilkan NPV positif

$\mathrm{i}_{2} \quad=$ Discount rate yang menghasilkan NPV negatif

$\mathrm{NPV}_{1}=\mathrm{NPV}$ positif

$\mathrm{NPV}_{2}=\mathrm{NPV}$ negatif 


\section{d. Payback Period (PP)}

Payback period (PP) adalah suatu periode yang menunjukkan waktu modal yang ditanamkan dalam bisnis akan kembali. Suatu usaha dikatakan layak apabila nilai pada payback period lebih cepat dari umur bisnis yang dijalankan (Sucipto, 2011). Perhitungan payback period dapat dilakukan dengan sebagai berikut:

\section{Keterangan:}

$$
\mathrm{PP}=\mathrm{n}+\frac{\mathrm{a}-\mathrm{b}}{\mathrm{a}-\mathrm{b}} \times 1 \text { tahun (4) }
$$

$$
\begin{array}{ll}
\mathrm{n} & =\text { tahun terakhir arus kas belumbisa menutup biaya investasi. } \\
\mathrm{a} & =\text { biaya investasi } \\
\mathrm{b} & =\text { biaya kumulatif cash flow tahun } \mathrm{n} \\
\mathrm{c} & =\text { biaya kumulatif cash flow tahun } \mathrm{n}+1
\end{array}
$$

e. Analisis nilai pengganti (Switching Value Analysis)

Analisis nilai pengganti adalah analisis untuk menghitung seberapa besar perubahan-perubahan yang dapat diterima oleh sebuah usaha. Perubahan berasal dari komponen arus kas masuk dan atau arus kas keluar. Analisis ini membantu pengusaha untuk mencari solusi dari permasalahan penurunan penjualan dan kenaikan harga bahan baku (Nurmalina et al., 2014).

\section{HASIL DAN PEMBAHASAN \\ Keragaan Pokdakan Mina Nila Sari Purwakarta}

Pokdakan Mina Nila Sari merupakan kelompok pembudidaya yang membudidayakan ikan nila Nirwana. Berlokasi di Kampung Legoksari, RT. 005 RW. 002 Desa Legoksari, Kecamatan Darangdan, Kabupaten Purwakarta, Provinsi Jawa Barat. Kelompok ini termasuk ke kelas kelompok pemula dan sedang dalam tahap penilaian untuk naik ke kelas madya. Didirikan pada tanggal 15 November 2015 oleh Bapak Didin Tajudin. Menurut Bapak Didin Tajudin, kelompok ini terbentuk atas hati nurani dan kesamaan tujuan antara calon anggota yang sebelumnya telah melakukan kegiatan pembenihan secara perseorangan. Selain itu, dorongan untuk terbentuknya kelompok ini adalah permasalahan-permasalahan yang dihadapi oleh para pembudidaya perorangan yaitu ketersediaan pakan dan pemasaran hasil.

Pada awal terbentuknya kelompok ini memiliki lahan sebesar 8000 meter persegi dan 18 anggota kelompok. Sampai saat ini, Pokdakan Mina Nila Sari beranggotakan 30 anggota dengan total luas lahan 76700 meter persegi. Kegiatan yang ada pada kelompok terdiri dari dua tahapan yaitu pembenihan dan pendederan. Pokdakan Mina Nila Sari merupakan kelompok bimbingan Dinas Peternakan dan Perikanan Kabupaten Purwakarta. Dinas Peternakan dan Perikanan Kabupaten Purwakarta memberikan dukungan kepada kelompok dalam bentuk pinjaman indukan ikan nila Nirwana sebanyak 43 paket. Setiap paket terdiri dari 100 ekor jantan dan 300 ekor betina. Dukungan ini menjadi stimulus bagi kelompok untuk meningkatkan produksi. Pokdakan Mina Nila Sari juga mendapatkan pembinaan teknis dari Dinas Peternakan dan Perikanan Kabupaten Purwakarta dan Balai Pengembangan Benih Ikan Nila dan Mas (BPBINM) Wanayasa untuk meningkatkan pengetahuan anggota dalam segi teknis budi daya maupun dalam hal pemasaran benih. 


\section{KELAYAKAN BISNIS ASPEK NON FINANSIAL Produk Pokdakan Mina Nila Sari Purwakarta}

Produk utama yang akan dipasarkan kepada konsumen berupa larva ikan nila Nirwana. Larva dipasarkan dengan satuan liter. Satu liter larva ikan nila Nirwana berisi 20000 ekor. Gambar larva setelah di panen dapat dilihat pada Gambar 1.

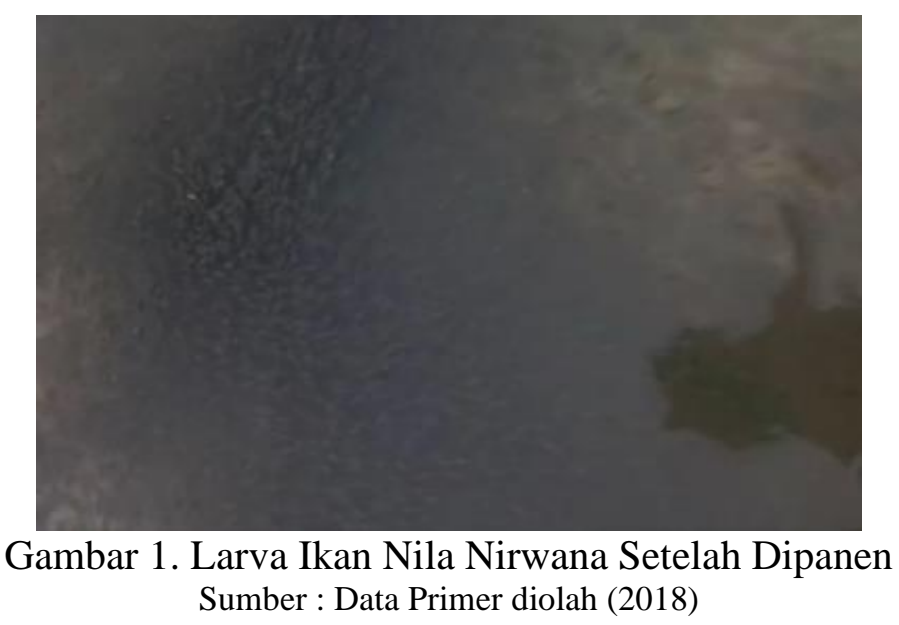

Larva akan dikemas ke dalam kemasan plastik yang berbentuk balon dan diisi air dan gas oksigen. Perbandingan air dan gas oksigen adalah sepertiga bagian diisi dengan air dan dua pertiganya diisi dengan oksigen. Kemasan tersebut didesain untuk pengiriman jarak jauh sehingga oksigen dalam kemasan dapat bertahan selama 24 jam. Gambar larva setelah dikemas dan akan dikirim dapat dilhat pada Gambar 2.

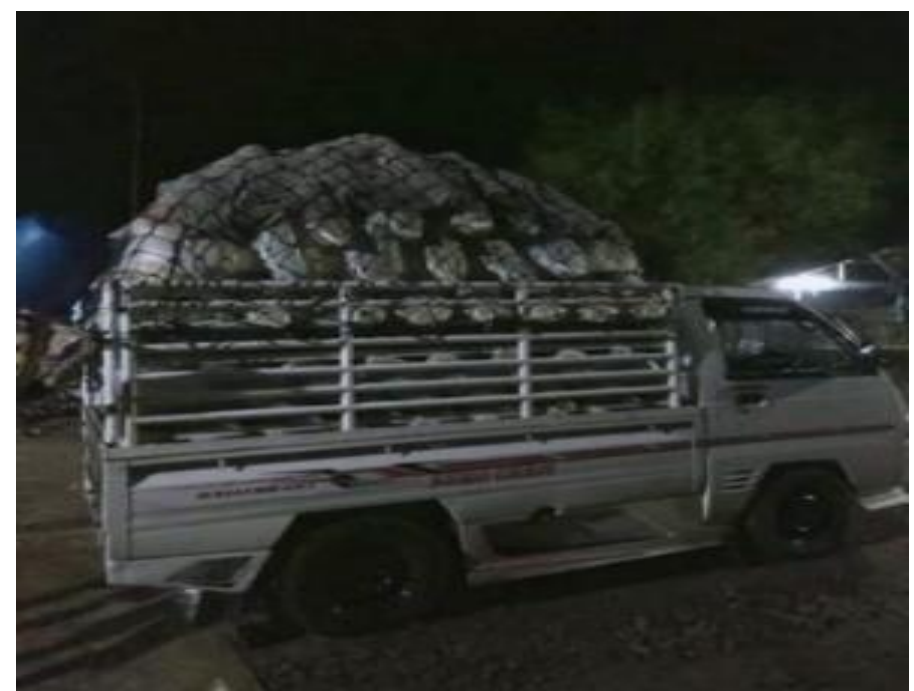

Gambar 2. Larva Setelah Dikemas Dan Dimuat Ke Dalam Mobil Sumber: Data Primer diolah (2018)

Produk sampingan yang akan dipasarkan adalah indukan ikan nila Nirwana yang telah afkir, yaitu indukan yang telah melakukan pemijahan selama 2 tahun. Bobot rata rata dari indukan afkir adalah 500 gram sampai 750 gram per ekor. 


\section{Pemasaran Pokdakan Mina Nila Sari}

Pengetahuan perusahaan tentang pasar yang dituju akan memudahkan distribusi produk. Perusahaan harus memiliki strategi pemasaran agar produk sampai ketangan konsumen yang tepat. Strategi pemasaran dibagi atas segementasi pasar, target pasar, posisi bisnis dalam pasar (postioning).

1. Segmentasi pasar

Segmen pasar dari produk utama secara faktor- faktor segmentasi pasar dibagi atas dua faktor yaitu faktor geografi, faktor demografi yang diuraikan sebagai berikut:

a. Faktor geografi

Produk utama dan produk sampingan secara geografi akan dipasarkan di wilayah Kabupaten Purwakarta. Kondisi alam yang dimiliki purwakarta sangat tepat untuk melaksanakan budi daya ikan nila Nirwana mulai dari tahap pembenihan hingga pembesaran. Kabupaten Purwakarta memiliki kualitas air sungai yang masih memadai untuk mengairi kolam-kolam budi daya ikan yang berasal dari sungai, irigasi, dan waduk.

b. Faktor demografi

Segmen berdasarkan faktor demografi merupakan pembudidaya yang akan membudidayakan ikan nila Nirwana tahap pendederan. Pembudidaya yang tergabung dalam kelompok pembudidaya sehingga permintaan konsumen dapat dipastikan keberlanjutan pasar.

2. Target pasar

Target pasar yang akan dituju untuk memasarkan produk utama dari bisnis yang dijalankan adalah pendeder anggota Pokdakan Mina Nila Sari yang berlokasi di wilayah Kabupaten Purwakarta. Produk sampingan akan dipasarkan kepada restauran dan industri pengolahan ikan nila dengan ukuran 500 - 750 gram per ekor.

3. Posisi pasar (Positioning).

Pokdakan Mina Nila Sari mnempatkan diri sebagai penyedia larva ikan Nila Nirwana yang berkualitas. Penerapan cara budi daya yang baik dan penanganan indukan yang baik menjadi daya jual bagi kelompok. Kepercayaan konsumen dibangun menggunakan perlakuan pascapanen yang menjamin kesehatan dan performa larva hingga dimasukkan ke kolam pendederan. Komunikasi dengan pendekatan kekeluargaan menjadikan nilai lebih ketika melakukan pemesanan.

4. Bauran pemasaran

Bauran pemasaran pada Pokdakan Mina Nila Sari berupa strategi produk, promosi, tempat, dan harga. Perumusan strategi menggunakan pendekatan tujuan, identifikasi masalah, penyelesaian masalah sehingga rumusan memiliki landasan yang kuat. Berikut penjelasan bauran pemasaran:

a. Produk (Product)

Produk utama yang akan dipasarkan kepada konsumen berupa larva ikan Nila Nirwana yang berumur 15 hari setelah induk dipijahkan. Larva tersebut merupakan larva yang telah melewati sortir sehingga larva siap untuk langsung dimasukkan ke kolam pendederan. Penciptaan produk ini diutamakan untuk memenuhi kebutuhan larva ikan nila Nirwana pada Pokdakan Mina Nila Sari. Larva ikan dihasilkan oleh induk ikan nila Nirwana dengan performa yang baik dan pengaturan masa pijah yang terjadwal sehingga tidak tercampur dengan ikan yang lain dan mempunyai ukuran seragam. Produk sampingan Pokdakan Mina Nila Sari adalah indukan afkir setiap 2 tahun sekali. 


\section{b. Promosi (Promotion)}

Strategi promosi bertujuan untuk memperkenalkan produk kepada konsumen. Produk akan diberitahukan spesifikasinya kepada calon pembeli. Strategi promosi yang digunakan berjenis telemarketing dan direct sales. Penggunaan telemarketing dan direct sales karena dapat menjangkau calon konsumen yang berada dimanapun dan Pokdakan Mina Nila Sari mendapat respon secara langsung.

c. Distribusi (Place)

Penjualan larva dalam pengembangan bisnis ini akan dijual ke anggota kelompok Pokdakan Mina Nila Sari. Indukan afkir didistribusikan ke restauran ikan bakar daerah cirata dan jatiluhur dan industri pengolahan ikan karena bahan baku ikan bakar adalah ikan yang memiliki berat minimal 500 gram per ekor. Rantai pemasaran dapat dilihat pada gambar

5.

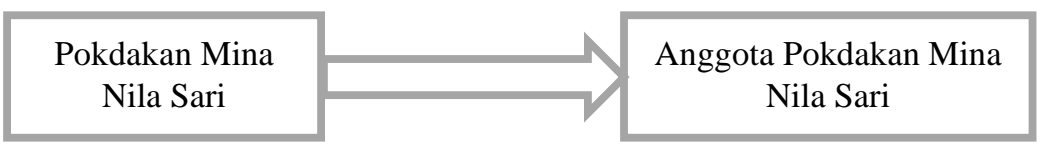

Gambar 3 Rantai Pemasaran Pengembangan Bisnis Sumber: Data Primer diolah (2018)

\section{d. Harga (Price)}

Harga jual larva Pokdakan Mina Nila Sari sebesar Rp 8.25 per ekor atau Rp 165.000 per liter. Harga sudah termasuk biaya pengiriman ke kolam pendederan. Harga untuk produk indukan afkir adalah $\mathrm{Rp} 11.000$ per ekor. Penentuan harga larva berdasarkan harga pokok penjualan dengan mark-up Rp 2,1. Mark up ditentukan dengan mempertimbangkan larva yang dihasilkan berasal dari varietas nila Nirwana yang dapat memberi keuntungan kepada pembudidaya.

\section{Produksi Pokdakan Mina Nila Sari}

1. Kapasitas Produksi

Kapasitas produksi dari Pokdakan Mina Nila Sari berdasarkan jumlah induk yang dimiliki. Induk yang dimiliki dibagi menjadi 3 kelompok induk. Produksi larva ikan memerlukan waktu 2 minggu mulai dari induk dimasukkan ke kolam pijah sampai dengan panen. Padat tebar untuk induk yang digunakan adalah 1 ekor $/ \mathrm{m}^{2}$ ). Kapasitas produksi setelah pengembangan mengalami peningkatan yaitu induk yang dimiliki meningkat menjadi 101 paket induk atau 40400 ekor dengan rasio antara jantan dan betina sebesar 1:3. Kapasitas produksi pada pengembangan bisnis per kelompok induk dapat dilihat pada Tabel 4.

Tabel 4. Kapasitas Produksi Pada Pengembangan Bisnis

\begin{tabular}{cclc}
\hline Induk & Jumlah (paket) & \multicolumn{1}{c}{ Jumlah (ekor) } & Produksi larva (000ekor) \\
\hline Kelompok A & 34 & 3.400 jantan & 11.000 \\
Kelompok B & 34 & 10.200 betina & \\
& & 3.400 jantan & 11.000 \\
Kelompok C & 33 & 3.300 jantan & 10.725 \\
Total & 101 & 9.900 betina & \\
\hline
\end{tabular}

Sumber: Data Primer diolah (2018) 


\section{Lokasi dan layout kolam budi daya}

Kolam yang dibutuhkan untuk mendukung kegiatan pembenihan berasal dari kolam anggota yang memiliki keterampilan pembenihan diatas anggota lain dan kolam gadai. Anggota yang memiliki keterampilan pembenihan berjumlah 10 orang dengan total luas kolam $17.200 \mathrm{~m}^{2}$. Penggunaan kolam sewa juga akan dikelola oleh 10 anggota kelompok yang memiliki kemampuan pembenihan. Kolam yang menjadi lokasi pembenihan tersebar dibeberapa lokasi di Desa Legoksari, Kecamatan Darangdan, Kabupaten Purwakarta sehingga terdapat kendala untuk mendapatkan data layout secara keseluruhan. Pokdakan Mina Nila Sari Purwakarta memiliki standar kolam yang telah digunakan seluruh anggota pokdakan. Kolam budi daya memiliki saluran inlet, pematang kolam, kemalir, kobakan, saluran outlet yang dapat dilihat pada Gambar 4 .
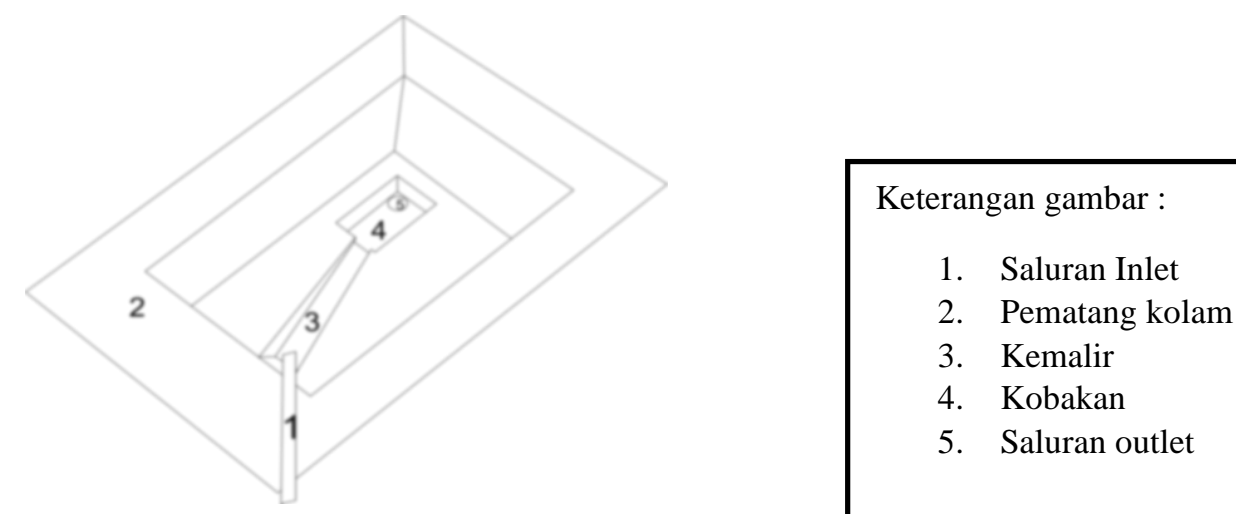

Gambar 4. Tata Letak Kolam Pembenihan Pada Pengembangan Bisnis Sumber: Data Primer diolah (2018)

\section{Proses produksi}

Proses budi daya ikan tahap pembenihan dimulai dari persiapan kolam sampai dengan pemanenan larva. Kegiatan ini saling berkaitan satu sama lain.

a. Pemeliharaan induk(Conditioning)

Pemeliharaan indukan dilakukan dengan memisahkan indukan betina dengan indukan jantan. Pemisahan dilakukan agar tidak terjadi perkawinan selama masa tunggu memijah dan pengembalian kondisi indukan untuk memijah kembali. Pemeliharaan dilakukan minimal selama 2 minggu sampai 1 bulan atau sampai jadwal memijah selanjutnya. Pemisahan dilakukan dengan cara mengambil indukan jantan dari kolam pemijahan dan memindahkan ke kolam pemeliharaan jantan.

b. Pemijahan

Pemijahan dilakukan dengan menggabungkan indukan jantan dan indukan betina. Penggabungan dilakukan dengan cara memindahkan indukan jantan ke kolam pemijahan yang telah tersedia indukan betina. Penggabungan dilakukan dengan memperhatikan sex ratio. Sex ratio untuk ikan nila yaitu (1:3) yang berarti 1 ekor indukan jantan akan membuahi 3 ekor indukan betina. Proses pemijahan dilakukan secara alami yang berasal dari gesekan tubuh indukan jantan dan indukan betina. Indukan betina akan mengeluarkan telur ke air dilanjut dengan semprotan sperma oleh indukan jantan sehingga pembuahan dilakukan di luar tubuh induk. Telur yang sudah dibuahi akan di masukkan ke dalam mulut indukan betina untuk dierami. Pengeraman dilakukan selama 2 hari. Ikan akan menetas didalam mulut indukan betina dan tetap berada dimulut indukan betina hingga cadangan makanan yaitu kuning telur habis 
sekitar 4 hari. Pemanenan larva dilakukan setelah 15 hari dihitung dari disatukannya indukan.

\section{c. Pemberian pakan}

Pemberian pakan pada indukan ikan nila secara restricted atau dibatasi dengan feeding rate 3\% dari biomassa induk. Pada saat pemijahan feeding rate $1 \%$ dari biomassa induk. Pakan yang digunakan adalah pakan merek dagang "BMA 281". Frekuensi pemberian pakan sebanyak 2 kali. Pemberian pakan dilakukan diantara jam 810 pagi dan 3-5 sore. Pemberian pakan ditebarkan ke kolam pada satu titik per $1.000 \mathrm{~m}^{2}$. d. Pemanenan larva

Panen larva dilakukan pada hari ke-15 dari indukan disatukan. Pemanenan larva dilakukan menggunakan alat waring (scoop net), ayakan, dan ember. Panen dilakukan dengan cara mengosongkan air hingga batas kobakan. Teknik ini digunakan karena memperhitungkan luas kolam. Larva yang telah berkumpul di dalam kobakan di ambil menggunakan waring dan ayakan dan dimasukkan ke dalam ember. Larva yang di dalam ember dimasukkan ke hapa yang telah dipasang di kolam lain.

\section{e. Pascapanen}

Kegiatan pascapanen pada tahap pembenihan yaitu mengemas ikan dengan plastik bening khusus ikan. Plastik dapat memuat 1 liter larva ikan nila Nirwana. Perbandingan antara gas oksigen dengan air adalah sepertiga diisi dengan air dan dua pertiga diisi dengan gas oksigen. Kemasan ini tahan selama 24 jam. Cara memuat larva ikan nila Nirwana ke plastik adalah mengambil ikan dengan ayakan kemudian meniriskan air di ayakan dan dilanjutkan memasukkan larva ke alat liter lalu ikan yang di alat liter dimasukkan ke plastik.

4. Hama penyakit dan penanganannya

Hama adalah organisme yang dapat menimbulkan gangguan pada ikan yang dibudidayakan baik secara langsung maupun tidak langsung. (Rahmaningsih, 2016). Penyakit adalah suatu keadaan fisik, kimia, biologis, morfologi, dan atau fungsi yang mengalami penurunan secara bertahap (Afrianto et al., 2015). Pencegahan dan penanganan hama dan penyakit harus diperhatikan secara intensif oleh para pembudidaya.

a. Hama dan penanganannya

1) Ikan lele dan belut

Ikan lele dan belut merupakan jenis ikan pemangsa, hama ini juga menyerang larva ikan dengan cara memakannya. Cara menanggulanginya yaitu memperbaiki pematang kolam setiap selesai panen dengan cara menutup lubang yang ada disekitar kolam.

\section{2) Kepiting}

Kepiting merupakan jenis hama yang dapat merusak pematang kolam dengan membuat lubang disekitar kolam, sehingga menyebabkan larva atau benih ikan keluar dari kolam. Cara menanggulanginya yaitu menggunakan insektisida dengan merek dagang decis.

b. Penyakit dan penanganannya

1) Bercak merah

Bercak merah merupakan penyakit yang disebabkan oleh bakteri Aeromonas dan Pseudomonas. Penyakit ini menyerang organ bagian dalam dan organ bagian luar ikan. Ikan yang terserang penyakit ini akan menjadi lemah dan muncul ke permukaan kolam. Serangan bakteri ini menyebabkan pendarahan pada tubuh ikan yang mengakibatkan munculnya borok pada kulit, sisik terkelupas, dan perut membusung. Cara 
menanggulanginya yaitu dengan memberikan daun pepaya yang sudah ditumbuk dan diletakkan di dekat sumber air.

2) Parasit

Parasit merupakan mikroorganisme yang menyerang bagian luar tubuh ikan seperti kulit, sirip, dan insang. Pencegahan serangan parasit ini bisa dillakukan dengan penurunan air kolam agar suhu air meningkat, sehingga ikan mendapatkan pencahayaan yang cukup.

5. Jadwal produksi

Penjadwalan sebuah proses produksi akan membantu pemilik dalam menghitung hari produksi. Implementasi terhadap jadwal yang telah direncanakan sebaiknya dijalankan dengan tepat. Satu siklus pembenihan memerlukan waktu 3 minggu dari mulai persiapan kolam hingga panen. Panen larva dilakukan pada akhir minggu ke-3. Setelah panen induk akan memasuki rematurasi selama 4 minggu hingga minggu ke-7 Siklus produksi dapat dilihat pada Tabel 5.

Tabel 5. Siklus Produksi Pembenihan

\begin{tabular}{llll}
\hline Deskripsi & 1 & 2 & 3 \\
\hline Persiapan kolam & & & \\
Pemijahan induk & & & \\
Panen larva & & & \\
\hline
\end{tabular}

Sumber: Data Primer diolah (2018)

\section{Organisasi Dan Manajemen}

1. Struktur Organisasi

Struktur Organisasi setelah pengembangan bisnis akan berubah menjadi seperti pada Gambar 5. Penyederhanaan dilakukan untuk memperpende birokrasi yang ada pada Pokdakan Mina Nila Sari. Seksi Produksi, Seksi Humas, Seksi Pemasaran, dan Seksi Sapras dihapus. Operasional di tanggung jawab oleh seorang Manajer. Manajer memberikan komando kepada penganggung jawab divisi pembenihan dan pendederan untuk melaksanakan tugas dan fungsinya. Tugas dari Manajer, Divisi Pembenihan dan Divisi Pendederan, yaitu:

a. Manajer

1) Menginformasikan ke dunia luar tentang potensi kelompok dan perkembangannya

2) Mencatat kondisi pasar dan menginformasikan balik ke anggota kelompok

3) Menjaga daya tawar pasar (Bargaining Position)

4) Mempertahankan dan mengembangkan pasar.

5) Membantu ketua mengawasi seluruh kegiatan bisnis.

b. Divisi Pembenihan

1) Mencatat perkembangan produksi tahap pembenihan dan melaporkan ke manajer produksi dan pemasaran

2) Mengusahakan peningkatan hasil produksi larva ikan

3) Mengadakan input produksi pembenihan

4) Menjaga ketersedian dan kualitas larva ikan

5) Menjaga kualitas indukan ikan

c. Divisi Pendederan

1) Mencatat perkembangan produksi tahap pendederan dan melaporkan ke manajer produksi dan pemasaran 
2) Mengusahakan peningkatan hasil produksi benih ikan

3) Mengadakan input produksi pendederan

Menjaga kualitas output pendederan

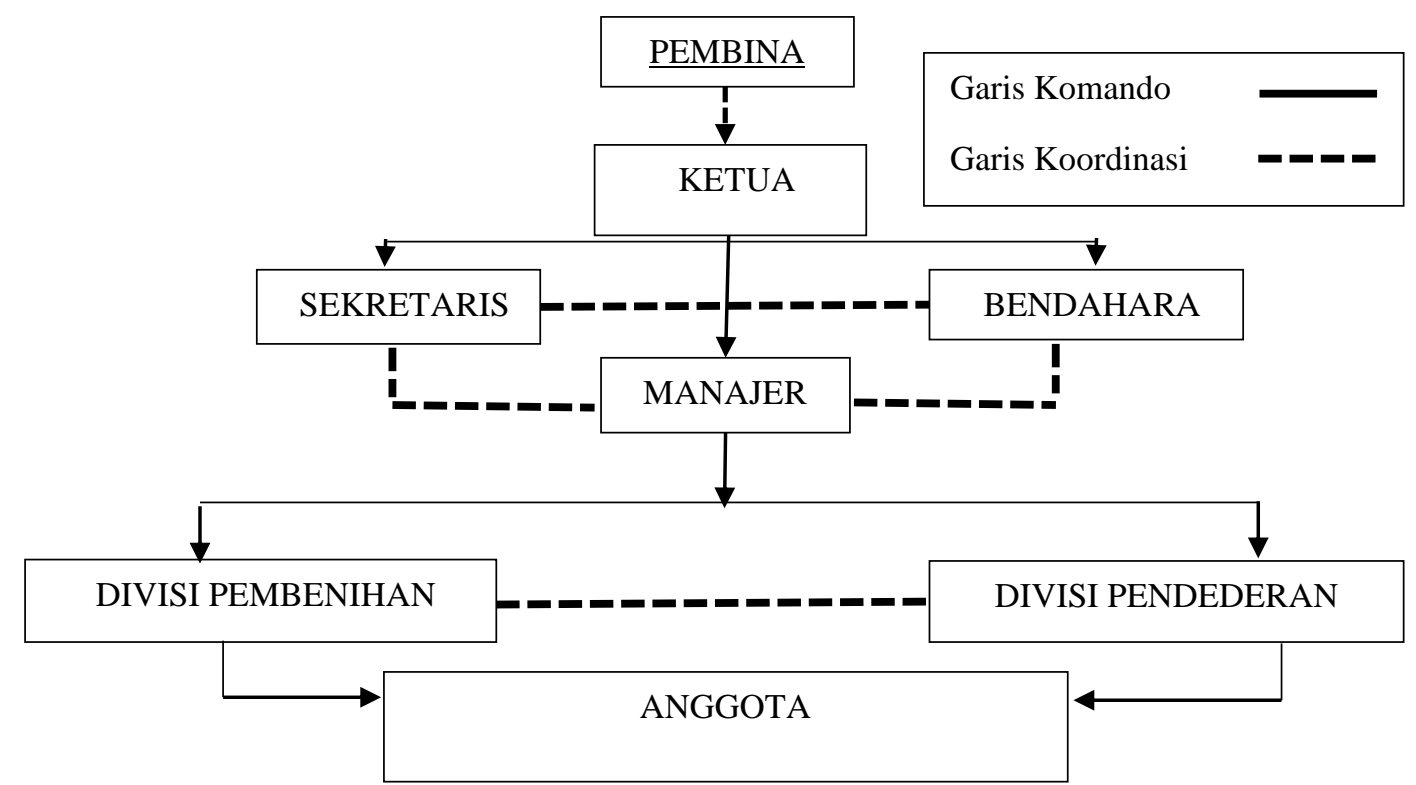

Gambar 5. Struktur Organisasi Pokdakan Mina Nila Sari

Sumber: Data Primer diolah (2018)

2. Budaya perusahaan

Budaya kerja pada sebuah Pokdakan diperlukan karena menggambarkan pengelolaan organisasi yang mempuni. Budaya kerja akan mendasari perilaku dan sikap pribadi anggota. Sikap dan perilaku dibentuk secara perlahan pada keseharian yang dijalani dalam Pokdakan yang mempunyai orientasi team work dan ontime delivery. Budaya kerja yang dimiliki Pokdakan Mina Nila Sari adalah disiplin waktu, bertanggung jawab, jujur, ulet, pekerja keras.

3. Pengambilan keputusan

Organisasi akan selalu dihadapkan dengan beberapa alternatif sehingga dalam memilih keputusan yang tepat diperlukan proses pengambilan keputusan yang baik. Keputusan yang akan dijalankan harus bersifat rasional, realistis, berpengaruh besar kepada kelompok. Pengambilan keputusan dalam Pokdakan Mina Nila Sari beradasarkan musyawarah mufakat.

\section{Sumber Daya Manusia Divisi Pembenihan}

Kebutuhan tenaga kerja dibagi menjadi 2 jenis yaitu Tenaga Harian Lepas (THL) dan tenaga kerja tetap. Tenaga kerja tetap bertugas memberi pakan setiap hari dengan gaji sebesar Rp 25.000 /hari kerja. Hari kerja pekerja tetap selama 365 hari per tahun. Tenaga harian lepas diberikan upah sebesar Rp 110.000 /HOK untuk seluruh pekerjaan dalam satu hari kerja. Hari kerja untuk tenaga kerja lepas selama 8 jam per hari. Tenaga kerja tetap diberikan 1 kali makan dan 2 kali makanan ringan dan tunjangan hari raya sebanyak satu kali gaji bulanan. 


\section{Kolaborasi}

1. Kolaborasi subsistem hulu

Pada susbsistem hulu Pokdakan Mina Nila Sari bermitra dengan pemasok pakan ikan. Pakan ikan dipasok oleh Usaha Dagang Bintang Mina Abadi. Sistem kemitraan yang digunakan adalah pembelian pakan yang dibayar pada saat panen.

2. Kolaborasi subsistem hilir

Pada subsistem hilir Pokdakan Mina Nila Sari bermitra dengan jasa transportasi perikanan. Pemilik jasa transportasi mengambil larva dari kolam pembenihan untuk diantarkan ke konsumen. Jasa transportasi sudah termasuk dengan plastik kemasan, karet, gas oksigen, pengemudi, dan bahan bakar minyak.

\section{Kelayakan Finansial}

Analisis finansial terhadap perencanaan bisnis diperlukan untuk menilai kelayakan sebuah bisnis dimasa sekarang sampai dengan dimasa depan. Analisis finansial yang dilakukan adalah menilai arus masuk (inflow) dan arus keluar (outflow), analisis kelayakan investasi serta analisis laba rugi. Penilaian terhadap rencana bisnis memerlukan asumsi-asumsi dasar yang menjadi acuan penilaian. Berikut asumsi-asumsi dasar dari bisnis budi daya perikanan:

a. Modal yang digunakan berasal dari modal pribadi, discount rate yang digunakan berasal dari bunga deposito PT. Bank Negara Indonesia 46 (BNI 46) sebesar 5\% per tahun.

b. Umur bisnis ditentukan berdasarkan komponen investasi yang memiliki umur terpanjang dan berpengaruh pada bisnis yaitu hapa induk yang berumur ekonomis 6 tahun. Hapa induk digunakan untuk menyimpan induk jika kolam sedang disiapkan atau diperbaiki.

c. Penerimaan berasal dari penjualan larva ikan nila Nirwana sebagai produk utama dan penerimaan tambahan berasal dari penjualan indukan afkir.

d. Harga jual larva sebesar Rp 8,25 per ekor atau Rp 165.000 per liter.

e. Harga jual induk afkir sebesar Rp 11000 per ekor.

f. Harga pada barang investasi kecuali kolam pribadi, biaya tetap, biaya variabel dihitung menggunakan harga yang berlaku dipasaran sekitar Pokdakan Mina Nila Sari pada tahun 2018 .

g. Harga komponen kolam pribadi pada biaya investasi berdasarkan harga beli pertama kali sebesar Rp $70.000 / \mathrm{m}^{2}$ (Pokdakan Mina Nila Sari 2018).

h. Satu paket induk berisi 400 ekor dengan rasio jantan dan betina sebesar (1:3) dengan umur produktif 2 tahun. Persentase penetasan (HR) $97 \%$ dari total jumlah telur. Survival rate sebesar 75\%. Satu ekor induk betina menghasilkan 1.500 butir telur.

i. Dosis pemberian pakan sebesar 3\% dari biomassa pada saat tidak memijah dan $1 \%$ dari biomassa pada saat pemijahan.

j. Komponen biaya pada rencana bisnis ini adalah biaya investasi dan biaya operasional.

k. Penyusutan menggunakan metode garis lurus dan nilai sisa berdasarkan survey pasar di sekitar lokasi usaha pada tahun 2018.

I. Pajak penghasilan ditentukan dari Peraturan Pemerintah No. 23 tahun 2018 sebesar $0.5 \%$ apabila peredaran bruto tidak melebihi Rp 4,8 Miliar.

1. Biaya Investasi 
Biaya investasi sebelum pengembangan sebesar $\mathrm{Rp}$ 1.222.665.000. Biaya investasi sebelum pengembangan lebih rendah dikarenakan induk dengan status kepemilikan pinjam. Proyeksi biaya investasi setelah pengembangan sebesar Rp 1.500.110.000. Proyeksi biaya investasi setelah pengembangan lebih besar karena bertambahnya kolam dan induk ikan yang bertambah dengan status kepemilikan menjadi milik sendiri.

2. Biaya Operasional

Biaya operasional merupakan hasil penjumlahan biaya tetap dan biaya variabel. Biaya operasional setelah pengembangan pada tahun pertama lebih kecil daripada tahun-tahun berikutnya karena produksi dimulai pada minggu ke 7. Proyeksi biaya operasional tahun pertama sebesar $\mathrm{Rp}$ 1.356.416.667 dengan rincian $\mathrm{Rp}$ 870.016.667 dari biaya tetap dan $\mathrm{Rp} 526.400 .000$ dari biaya variabel. Proyeksi biaya operasional pada tahun selanjutnya sampai dengan tahun kesepuluh sebesar Rp 1.568.321.667 yang berasal dari biaya tetap sebesar Rp 1.000.341.667 dan biaya variabel sebesar Rp 567.980.000.

3. Proyeksi Penerimaan

Penerimaan setelah pengembangan bisnis berasal dari penjualan produk utama, produk sampingan, nilai sewa, dan nilai sisa. Proyeksi total penerimaan setiap tahunnya berbeda, perbedaan berasal dari penerimaan penjualan produk sampingan 2 tahun sekali Proyeksi penerimaan dapat dilihat pada Tabel 6.

Tabel 6. Proyeksi Penerimaan Setelah Pengembangan Bisnis

\begin{tabular}{|c|c|c|c|c|c|c|}
\hline \multirow{2}{*}{ Penerimaan } & \multicolumn{6}{|c|}{ Tahun (Juta Rupiah) } \\
\hline & 1 & 2 & 3 & 4 & 5 & 6 \\
\hline Penjualan larva & 1.746 & 1.984 & 1.984 & 1.984 & 1.984 & 1.984 \\
\hline $\begin{array}{l}\text { Penjualan induk } \\
\text { afkir }\end{array}$ & & 404 & & 404 & & 404 \\
\hline Total penerimaan & 1.746 & 2.388 & 1.984 & 2.388 & 1.984 & 2.388 \\
\hline
\end{tabular}

Sumber: Data Primer diolah (2018)

Penerimaan sebelum pengembangan bernilai sama setiap tahun. Hal yang menyebabkan penerimaan pada sebelum pengembangan sama setiap tahun adalah sumber penerimaan hanya berasal dari penjualan larva. Penerimaan sebelum pengembangan dapat dilihat pada Tabel 7.

Tabel 7. Penerimaan Sebelum Pengembangan Bisnis

\begin{tabular}{ll}
\hline Penerimaan tahun ke- & Jumlah $(\mathrm{Rp})$ \\
\hline 1 & 881.377 .500 \\
$2-6$ & 881.377 .500 \\
\hline
\end{tabular}

Sumber: Data Primer diolah (2018)

4. Proyeksi Laba Rugi

Tabel 8. Proyeksi Laba Rugi

\begin{tabular}{lcccccc}
\hline \multirow{2}{*}{ Komponen } & \multicolumn{5}{c}{ Tahun ke- (Rp 000) } \\
\cline { 2 - 6 } & 1 & 2 & 3 & 4 & 5 & 6 \\
\hline Laba bersih & 383.493 & 807.738 & 405.758 & 807.738 & $405.758 ; 07.738$ \\
\hline Sumber: Data Primer diolah (2018) & & & &
\end{tabular}


Berdasarkan Tabel 8, proyeksi laba bersih setelah pengembangan bisnis ini hasil dari tahun pertama sudah bernilai positif yang artinya pengembangan bisnis ini telah menghasilkan laba bersih positif dari mulai tahun pertama.

\section{Analisis Arus kas}

Komponen yang mengisi arus kas adalah arus kas masuk, arus kas keluar, manfaat bersih, dan kriteria-kriteria investasi. Net Present Value (NPV), Internal rate of return (IRR), Net Benefit/Cost Ratio, dan Payback Period merupakan kriteria investasi yang digunakan untuk menganalisis arus kas dalam pengembangan ini. Hasil analisis arus kas akan dibandingkan antara arus kas sebelum pengembangan (tanpa pengembangan bisnis) dengan arus kas pengembangan bisnis (dengan pengembangan bisnis). Hasil analisis akan memberikan informasi terkait apakah pengembangan bisnis ini menguntungkan. Hasil analisis arus kas dapat dilihat pada Tabel 9.

Tabel 9. Hasil Analisis Kriteria Investasi Pada Arus Kas Sebelum Pengembangan Bisnis

\begin{tabular}{llll}
\hline Kriteria investasi & Kriteria kelayakan & Analisis kriteria investasi & $\begin{array}{l}\text { Hasil } \\
\text { Keputusan }\end{array}$ \\
\hline NPV $(\mathrm{Rp})$ & $>0$ & 1.565 .247 .510 & Layak \\
IRR $(\%)$ & $>$ DR & 73.71 & Layak \\
Net B/C & $>1$ & 2,05 & Layak \\
Payback Period & $>$ umur bisnis & $2,35(2$ tahun 4 bulan 6 hari $)$ & Layak \\
\hline
\end{tabular}

Sumber: Data Primer diolah (2018)

Berdasarkan Tabel 9, hasil dari kriteria investasi Net B/C mendapat nilai 2.05 yang berarti setiap Rp 1 yang dikeluarkan akan menghasilkan penerimaan sebesar Rp 2.05. NPV sebesar Rp. 1.565.247.510. IRR sebesar 73.71\% lebih besar dari suku bunga pembanding yaitu 5\%. Pengembalian investasi sebelum pengembangan bisnis selama 2 tahun 4 bulan 6 hari. Berbeda dengan Tabel 11, Hasil analisis kriteria investasi setelah pengembangan bisnis penambahan induk ikan nila Nirwana yaitu kriteria investasi Net B/C mendapat nilai 3.07 yang berarti setiap Rp 1 yang dikeluarkan akan menghasilkan penerimaan sebesar Rp 3.07. NPV sebesar 1.914.645.194. IRR sebesar 69\%, lebih besar dari discount rate sebesar 5\%. Pengembalian investasi setelah pengembangan diproyeksikan selama 2 tahun 2 bulan 23 hari. Hasil dari Situmorang dkk. (2017), Unit Pembenihan Rakyat (UPR) di Kabupaten Klaten memiliki nilai B/C rasio dan NPV yang lebih kecil dari Pokdakan Mina Nila Sari yaitu maksimal 1,73 dan Rp 280.130.514. Perbedaan nilai dapat berasal dari volume usaha yang berbeda serta strain ikan nila yang digunakan berbeda. Nilai kriteria investasi setelah pengembangan dapat dikatakan menguntungkan karena nilai yang didapat diatas nilai minimal yang harus dicapai. Hasil analisis kriteria investasi pada arus kas pengembangan bisnis induk ikan nila Nirwana dapat dilihat pada Tabel 10.

Tabel 10. Hasil Analisis Kriteria Investasi Pada Arus Kas Setelah Pengembangan Bisnis

\begin{tabular}{llll}
\hline Kriteria investasi & Kriteria kelayakan & Analisis kriteria investasi & $\begin{array}{l}\text { Hasil } \\
\text { Keputusan }\end{array}$ \\
\hline NPV (Rp) & $>0$ & 1.914 .645 .194 & Layak \\
IRR $(\%)$ & $>$ DR & 69 & Layak \\
Net B/C & $>1$ & 3,07 & Layak \\
Payback Period & $>$ umur bisnis & $2,23(2$ tahun 2 bulan 23 hari $)$ & Layak \\
\hline
\end{tabular}

Sumber: Data Primer diolah (2018) 
Pengembangan bisnis juga dianalisis dengan menggunakan arus kas Incremental Net Benefit untuk mengetahui seberapa besar manfaat tambahan dari pengembangan bisnis. Hasil dari analisis analisis arus kas Incremental Net Benefit dapat dilihat pada Tabel 11.

Tabel 11. Hasil Analisis Arus Kas Incremental Net Benefit

\begin{tabular}{llll}
\hline Kriteria investasi & Kriteria kelayakan & Analisis kriteria investasi & Hasil \\
\hline NPV (Rp) & $>0$ & 349.397 .684 & Layak \\
IRR $(\%)$ & $>$ DR & 53 & Layak \\
Net B/C & $>1$ & 1,51 & Layak \\
Payback Period & $>$ umur bisnis & $0,73(8$ bulan 23 hari $)$ & Layak \\
\hline Se
\end{tabular}

Sumber: Data Primer diolah (2018)

Berdasarkan Tabel 11, pengembangan bisnis penambahan induk ikan nila akan mendapatkan tambahan manfaat bersih sebesar Rp 349397684 dan Net B/C rasio sebesar 1.51. Pengembalian investasi 0,73 tahun lebih cepat. Hasil analisis kriteria investasi pada arus kas secara keseluruhan, pengembangan bisnis penambahan induk ikan nila Nirwana layak untuk dijalankan.

6. Analisis switching value

Analisis dari nilai pengganti akan memberikan informasi kepada pemilik tentang toleransi-toleransi perubahan yang dapat diterima pada pengembangan bisnis. Pengembangan bisnis ini di analisa dengan 2 faktor yaitu penurunan produksi atau peningkatan biaya pembelian pakan. Hasil dari analisis nilai pengganti dapat dilihat pada Tabel 12.

Tabel 12. Hasil Analisis Switching Value

\begin{tabular}{llllll}
\hline Uraian & Persentase (\%) & NPV (Rp) & IRR (\%) & Net & PP \\
\hline Perhitungan arus kas & & 1.914 .645 .194 & 69 & 3,07 & 2,23 \\
Penurunan produksi larva & 115 & 0 & 5 & 1 & 6 \\
Peningkatan biaya pembelian pakan & 446 & 0 & 5 & 1 & 6 \\
\hline
\end{tabular}

Sumber: Data Primer diolah (2018)

Berdasarkan Tabel 12, penurunan produksi larva merupakan resiko yang kemungkinan paling besar yang terjadi pada usaha pembenihan nila. Penurunan produksi dapat mempengaruhi kelayakan dari usaha pembenihan. Hasil analisis switching value penurunan produksi larva yang dapat ditoleransi pengembangan bisnis ini maksimal sebesar $115 \%$ untuk tetap berada di titik impas. Begitu pula dengan peningkatan biaya pembelian pakan, jumlah pakan secara serentak berpengaruh signifikan terhadap produksi larva. Keeratan hubungan jumlah pakan dengan jumlah larva yang dhasilkan sebesar 60,5\% (Prahasti et al., 2018). Kenaikan harga pakan akan dapat mengurangi pemberian pakan oleh pembudidaya ikan. Kenaikan harga pakan yang dapat di toleransi maksimal dalam pengempangan bisnis ini sebesar $446 \%$ untuk tetap berada pada titik impas. Hasil analisis Switching Value menjelaskan bahwa pengembangan bisnis tidak sensitif terhadap resiko yang mungkin terjadi disebabkan besarnya penerimaan penjualan produk sampingan setiap 2 tahun.

\section{SIMPULAN}

Kelompok Mina Nila Sari adalah Pokdakan memiliki usaha utama pembenihan dan pendederan ikan Nila Nirwana. Kekuatan Pokdakan Mina Nila Sari Purwakarta merupakan nilai utama dalam pengembangan ini untuk memanfaatkan peluang yang ada pada lingkungan bisnis perikanan. Sumber daya manusia yang dimiliki dengan 
pengalaman pemijahan induk, kebutuhan benih yang tinggi dari dalam kelompok, serta daya dukung lingkungan yang baik memberikan kepastian terhadap rencana pengembangan bisnis yang dilakukan oleh Pokdakan Mina Nila Sari Purwakarta. Pengembangan bisnis ini juga dinilai berdasarkan tingkat kelayakan untuk diinvestasikan. Analisis yang digunakan untuk mengetahui kelayakan pengembangan ini melalui dua aspek yaitu, aspek non finansial dan aspek finansial. Hasil dari analisis terhadap aspek non finansial, pengembangan ini dapat dikatakan layak karena produk yang dijual adalah larva ikan nila Nirwana dengan konsumen anggota kelompok Pokdakan Mina Nila Sari Purwakarta. Struktur organisasi dan budaya kerja yang baik dapat mendorong semangat untuk selalu produktif. Sumber daya manusia di lokasi pokdakan yang mayoritas sebagai petani dan pembudidaya ikan dapat memenuhi kebutuhan tenaga kerja lepas pokdakan. Aspek finansial dinilai berdasarkan tercapainya nilai minimal dari kriteria kelayakan analisis kriteria investasi.

Hasil dari analisis kriteria investasi pada arus kas pengembangan bisnis ini memiliki nilai Net Present Value (NPV) sebesar Rp 1.914.645.194 dikatakan layak karena NPV bernilai diatas nilai minimal kriteria kelayakan yaitu diatas Rp. 0. Internal Rate of Return (IRR) sebesar 69\% dikatakan layak karena diatas nilai minimal kriteria kelayakan analisis kriteria investasi yaitu diatas suku bunga diskonto sebesar 5\%. Net Benefit/Cost sebesar 3,07 dikatakan layak karena memiliki nilai diatas nilai minimal kriteria kelayakan yaitu diatas 1. Payback Period (PP) sebesar 2,23 atau 2 tahun 2 bulan 23 hari dikatakan layak karena diatas nilai minimal kriteria kelayakan yaitu lebih cepat dari umur bisnis selama 6 tahun. Penambahan Induk Ikan nila Nirwana agar segera dilaksanakan karena tidak adanya kepastian keberlanjutan dari program Bantuan Peminjaman Indukan (Bapinduk) Ikan nila Nirwana yang dikelola oleh Balai Pengembangan dan Pemacuan Stok Ikan Nila dan Mas (BPPSINM) dan kelompok belum memiliki induk ikan nila Nirwana secara mandiri.

\section{DAFTAR PUSTAKA}

Afrianto, E., Liviawaty, E., Jamaris, Z., \& Hendi. (2015). Penyakit Ikan. Penebar Swadaya.

Amarullah, T., Zuriat, Z., Zuraidah, S., \& Mustika, D. (2020). Prospek Usaha Pembenihan Ikan Nila Gift (Oreochomis Nilotikus,Sp) Di Kabupaten Nagan Raya Propinsi Aceh. Jurnal Bisnis Tani, 6(1), 16-25.

Diatin, I., Sobari, M. P., Irianni, D. R., Perikanan, F., Kelautan, I., \& Bogor, I. (2007). Analisis Kelayakan Finansial Budidaya Ikan Nila Wanayasa Pada Kelompok Pembudidaya Mekarsari. Jurnal Akuakultur Indonesia, 6(1), 97-102.

Kasmir, \& Jakfar. (2003). Studi Kelayakan Bisnis. Kencana.

Kotler, P., \& Amstrong, G. (2017). Manajemen Pemasaran (A. Maulana, D. Barnadi, \& W. Hardani (ed.); 12 ed.). Penerbit Erlangga.

Nurmalina, R., Sarianti, T., \& Karyadi, A. (2014). Studi Kelayakan Bisnis (M. C. Kurniawan (ed.)). IPB Press.

Pokdakan Mina Nila Sari. (2018). Penawaran dan Permintaan Larva Pokdakan Mina Nila Sari. Kelompok Pembudidaya Ikan Mina Nila Sari Purwakarta

Pomuri, C., Suhaeni, S., \& Kotambunan, O. V. (2020). Analisis Kelayakan Usaha Pembenihan Ikan Mas (Cyprinus Carpio L) Pada Usaha Perikanan Rakyat (UPR) 
Syariah Mandiri Di Kelurahan Motoboi Kecil, Kota Kotamobagu Provinsi Sulawesi Utara. AKULTURASI Jurnal Ilmiah Agrobisnis Perikanan, 8(1), 24-34.

Prahasti, D. N., NQ, L., \& Irwan. (2018). Analisis Faktor-Faktor Yang Mempengaruhi Produksi Dan Pendapatan Pembenihan Nila Ras Wanayasa (Nirwana) Pada Kelompok Pembudidaya Ikan Di Kecamatan Wanayasa, Kabupaten Purwakarta. Skripsi. Fakultas Ekonomi dan Bisnis Universitas Pasundan.

Raharja, S. J. (2009). Kolaborasi Sebagai Strategi Bisnis Masa Depan. Jurnal Administrasi Bisnis, 5(1), 44-53.

Rahmaningsih, S. (2016). Hama dan Penyakit Ikan. DeePublish.

Situmorang, N., Elfitasari, T., \& Sarjito. (2017). Analisis Usaha Unit Pembenihan Rakyat (UPR) Pendederan Ikan Nila (Oreochromis sp) dengan Pola Kemitraan di Kecamatan Tulung Kabupaten Klaten Jawa Tengah. Journal of Aquaculture Management and Technology, 6(4), 148-156.

Sucipto, A. (2011). Studi Kelayakan Bisnis. UIN MALIKI Press. 